\title{
Simulation Model of Hybrid Shunting Locomotive
}

\author{
Zdeněk Mašek ${ }^{1)}$, Václav Lenoch ${ }^{2)}$ and Tomáš Lelek ${ }^{3)}$ \\ 1) 2) 3) University of Pardubice, The Jan Perner Transport Faculty, Department of Electrical and Electronic Engineering \\ and Signalling in Transport (KEEZ), Czech Republic, \\ e-mail: ${ }^{1)}$ zdenek.masek@upce.cz, ${ }^{2)}$ vaclav.lenoch@upce.cz, ${ }^{3)}$ tomas.lelek2@upce.cz
}

\begin{abstract}
The paper describes the simulation model of the hybrid shunting locomotive. The hybrid drive consists of the diesel engine supplemented with lithium batteries. The simulation model is created in order to analyse energy flows, determine influence of the component proper size and control strategy.
\end{abstract}

Keywords - simulation model, series hybrid drive, control strategy, shunting locomotion, diesel engine, lithium battery, traction motor, generator, energy power flow, efficiency

\section{INTRODUCTION}

Hybrid electric drives are more common in automotive segment rather than in rail vehicles. On the other hand rail vehicles offer better conditions for the hybrid electric drive utilization. The benefits are: fixed routes, easier power-pack integration to the vehicle, shunting duty with many stops and accelerations, better utilized recuperation, higher weight of vehicles and lower rolling resistance. The simulation model for analysis of energy flows in propulsion of the rail vehicle was created at the KEEZ department at the Jan Perner Transport faculty at University of Pardubice as a part of the CKDV project. The simulation model was used to analyse contribution of rebuilding locomotive class 744 (made by CZ Loko a.s.) used in shunting service from the diesel-electric to hybridelectric propulsion. The series hybrid drive was selected because of shunting duty with many stops. The class 744 is a four-axle diesel-electric (AC/AC) locomotive for shunting and line service with the nominal weight 74 tons. The primary power source is the Caterpillar diesel engine C3508C with $970 \mathrm{~kW}$ connected to the Siemens synchronous traction alternator with an exciter (Fig. 1).

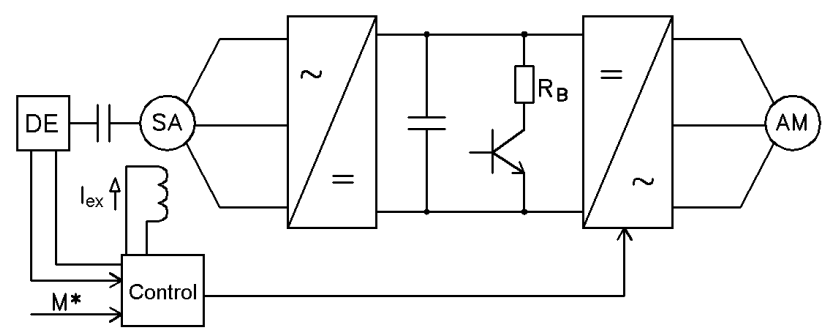

Fig. 1 Principal structure of the locomotive 744 drive.

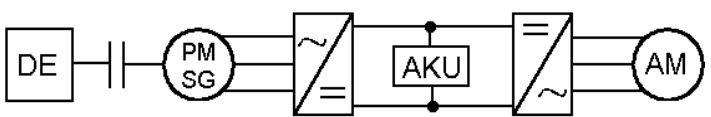

Fig. 2 Series-hybrid propulsion.

These components are used in the model with hybrid propulsion: PMSG instead of synchronous alternator with exciter and Li-Titanat batteries connected directly to the $750 \mathrm{~V}$ DC-bus without converter. Supercapacitors are not used due to high cost and are not necessary due to high charge current (5-6C) of Li-Ti batteries. The diesel engine power is reduced to approximately half. The saved weight is used for batteries up to the nominal vehicle weight 74 tons. All auxiliary power consumption is fed from the electric bus. The control strategy ensures optimal utilization of the diesel engine power and reduces running in idle (locomotive used in shunting service usually spends more than $40 \%$ of time in idle).

\section{SIMULATION SOFTWARE}

The main purpose of the created simulation software is the analysis of energy flows, power flows and efficiencies in the propulsion system in the predefined drive cycle. The software can be used for analysis of an existing vehicle or vehicle in development. Some preparation is made before the model can be run (simplified):

- Definition of vehicle parameters, propulsion structure and components.

- Drive cycle definition - static speed profile, grade profile, position of stops, time spent at stops and train weight profile.

Many quantities of each block in the simulation model are logged during simulation. At the end of the simulation we can get answers on our questions:

- Is train capable to fulfil the drive cycle?

- How much energy (fuel) was consumed?

- How did energy quantity in batteries change?

- What is the peak power of the diesel engine and batteries?

- Which point each component works at? What are the efficiency points that components works at? 


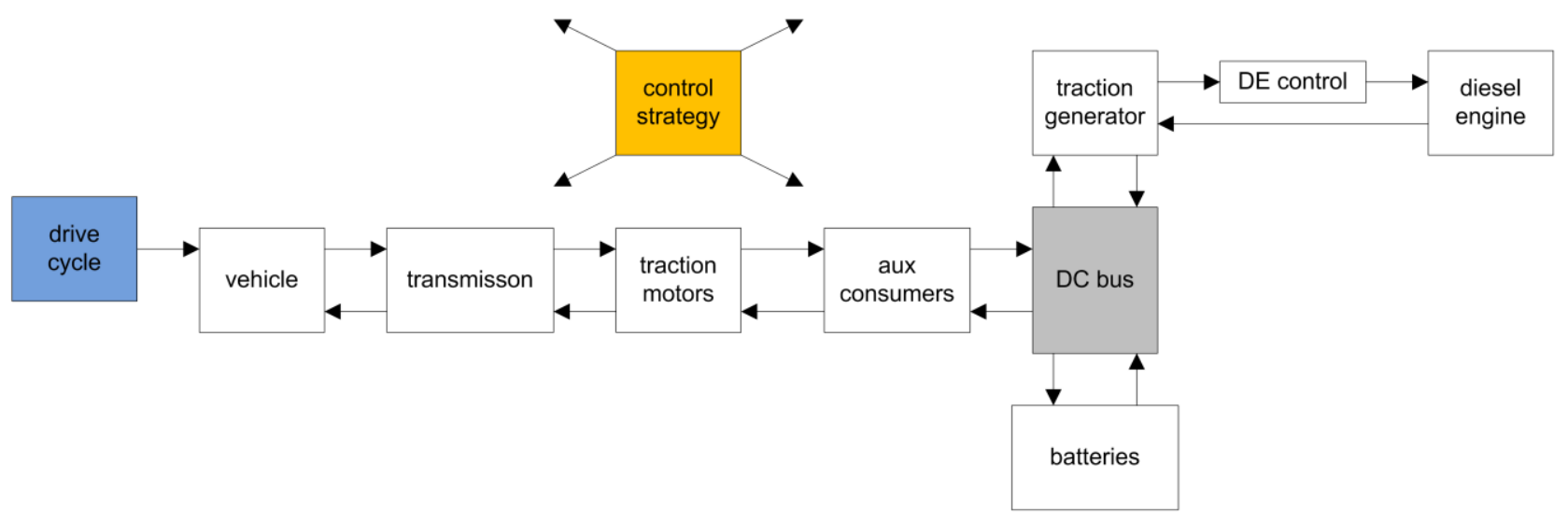

Fig. 3 Structure of the simulation model.

The software enables various type of simulations of vehicles and propulsions in general. Component models are stored in libraries. If a component does not exist user can create it (he/she has to have programming skills). The software is created in Matlab/Simulink. Models of components and the whole simulation model are created in Simulink, Matlab scripts and functions are used to store model parameters, to control the simulation and to analyze logged data from simulations.

Component models (i.e. traction motor, generator, combustion engine, transmission, batteries, converters etc.) are modeled quasi-statically. Parameters defined in the steady-state are used. The dynamic part is modeled by moment of inertia in most cases. The main parameter of each component is the efficiency map. These maps are created from measured data and stored in look-up tables or are calculated from analytic equations which describe relation between the input and output power for each operating point. The proposed method does not require detailed set of component parameters. Detailed parameters are not usually available from manufacturer. Nominal parameters of the components and well known common physical behavior of the component are sufficient for setting up the model in most cases. The simulation model is not designated for modeling fast transients. The simulation time step is about $0.1 \mathrm{~s}$ which ensures enough accuracy and acceptable simulation time (vehicle running tenths of kilometers).

\section{Simulation Model StRUCTURE}

The term "simulation model" means the whole simulation model of the vehicle (or train) that is created from models of the traction drive, control strategy, vehicle parameters and drive cycle. The signal flow in the model is as follows. The power demand (force demand) from wheels is generated at first according to the drive cycle and rolling resistance of the train. This power demand is recalculated through the efficiency map of each component upwards, the power demand of the auxiliary machinery is added and the final power demand to primary energy source (combustion engine or batteries or both) is calculated. The power demand can exceed the maximum power that can deliver the primary source or any component in the proposed path. In this case the power demand is limited. The final power demand is then propagated back to wheels through each component.
Efficiencies of each component play a role again when the operating point has changed. The structure of the simulation models is shown in Fig. 3.

There is a forward and backward path in the model according to direction of power flows (Fig. 4). In the forward path (upwards direction - from wheels up to the primary source) the desired power input is calculated from the desired power output in each block. In the backward path (downwards direction - from the primary source down to wheels) the available output power is calculated from the input power in each block.

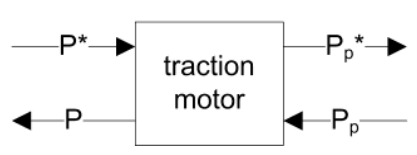

$\mathrm{P}^{*}$ - power output demand

$\mathrm{P}_{\mathrm{p}} *$ - power input demand $\mathrm{P}_{\mathrm{p}}$ - available input power $\mathrm{P}-$ available output power

Fig. 4 Forward and backward paths.

In each direction a limitation of power can occur and efficiencies can differ because of a different operating point. The actual vehicle (train) speed can differ from the desired speed dictated by the drive cycle if there is not enough power.

The control strategy block controls the power distribution between more power sources. Communication between blocks in the model is implemented with global references (global tags named according to block name).

Basic inputs to the simulation model:

- Drive cycle - static speed profile, grade profile, position of stops, time spent at stops, train weight profile.

- Rolling resistance of locomotive and coaches.

- Adhesion weight.

- Maximum acceleration and deceleration.

- Component parameters - nominal parameters (voltages, currents, weight, speed, inertia etc.), maximum parameters, fuel consumption map in case of the diesel engine.

Basic outputs from the simulation model:

- Speed demand and real speed of the vehicle (train). 
- Total energy consumed (total fuel consumed).

- Power flows, current flows, voltage, speed, torque if applicable.

- $\quad$ Tractive force, braking force, recuperated power/energy.

- Battery state of charge.

\section{MODELS OF COMPONENTS}

This section describes models of some components used in the simulation model. The simulation software is modular. Each type of the component has its own block. Blocks are connected together via lines and global tags in Simulink.

\section{A. Overview}

In case of the hybrid vehicle it is important to calculate the most accurate power and energy flows in order to calculate energy and cost savings and to check proper sizing of components that influences battery life and operating range of the vehicle.

There are typical loss-making components in the hybrid electric vehicle: electric machines (motors, generators, transformers), converters, mechanical transmissions, batteries, combustion engines. Precise calculation of losses at every operating point is difficult because component parameters are often not constant (i.e. winding resistance of electric motor) and access to the detailed parameters of the modeled component is simply not available in many cases. The most easiest way is to use constant effciencies which can be used only if efficiencies are high (95 percent or more). In case of the hybrid vehicle this apporach can be used with the mechanical transmissions and electric power converters. Both types of components are complicated nonlinear systems, detailed information is mostly not available, creation of a general model for precision improvement is not easy and is not worth of money. In case of mechanical transmissions the type of lubrication and its properties are the main source of inaccuracy. In case of power converters modeling of switching behaviour is not easy in addtition to long simulation step used in the whole simulation model.

\section{B. General Structure of Component Model}

Almost every model basically has two inputs and two outputs.

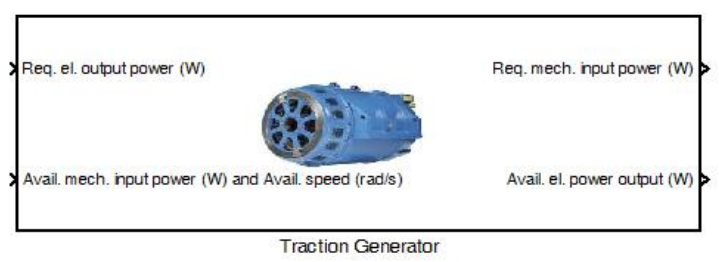

Fig. 5 Traction generator block.

Inputs (on the left side): desired electric power output, available mechanical power input and speed.

Outputs (on the right side): mechanical power input demand, available electric power output.
Models provide not only information about the power flows but also additional information about the operating point (torque, speed, etc.) in order to be able to calculate efficiency at the operating point. Data fed to/from each port are collected to a bus. There is a hidden input named Control to influence the model according to the selected control strategy. The hidden otuput Sensors is used for data logging during simulation. The Control input and Sensors output are not visible from the top level, there are no ports to connect. They are implemented at lower levels of the block as global tags named according to the block name in Simulink (Fig. 6).

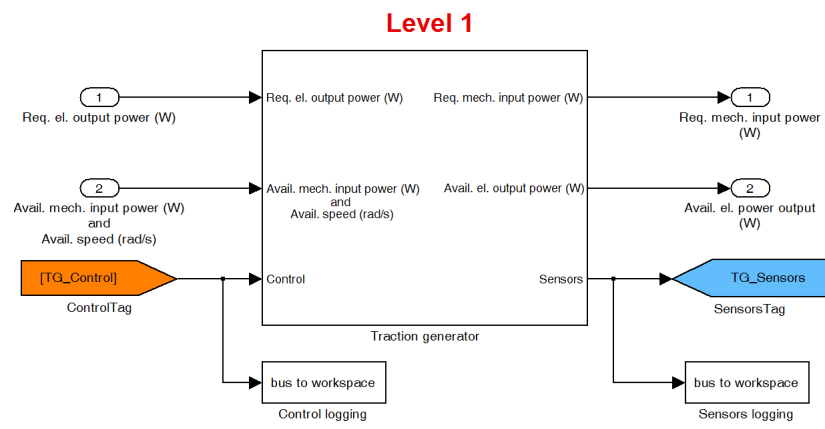

Fig. 6 Level 1 of the traction generator block.

Communication with the block is done with these inputs and outputs:

- Input and output ports (power input, output, torque, speed) - top level, connection between blocks via lines.

- Control input for additional control data - level 1 of the block (hidden to user), access via tags.

- Sensors output for logged data - level 1 of the block (hidden to user), access via tags.

- Block initialization is done via m-file (in block mask level), this assigns the block to particular component (for example $186 \mathrm{kVA}$ PMSG), see Fig. 7.

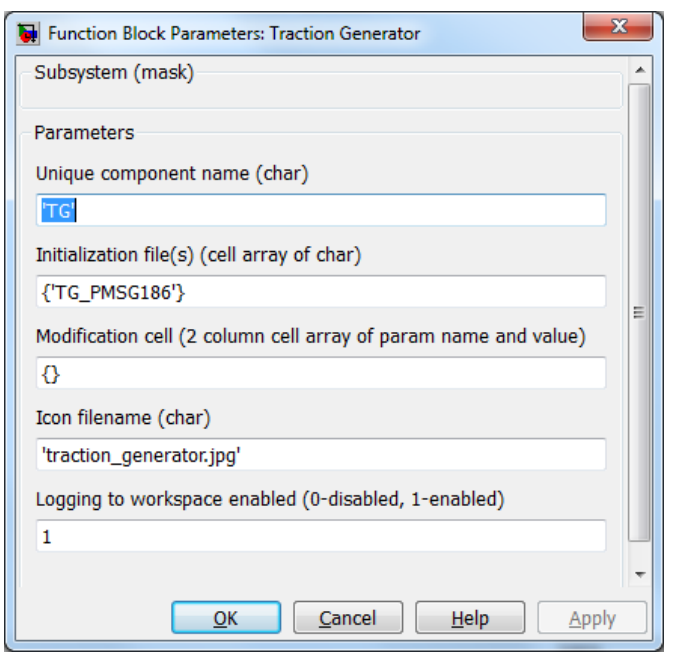

Fig. 7 Block parameters. 


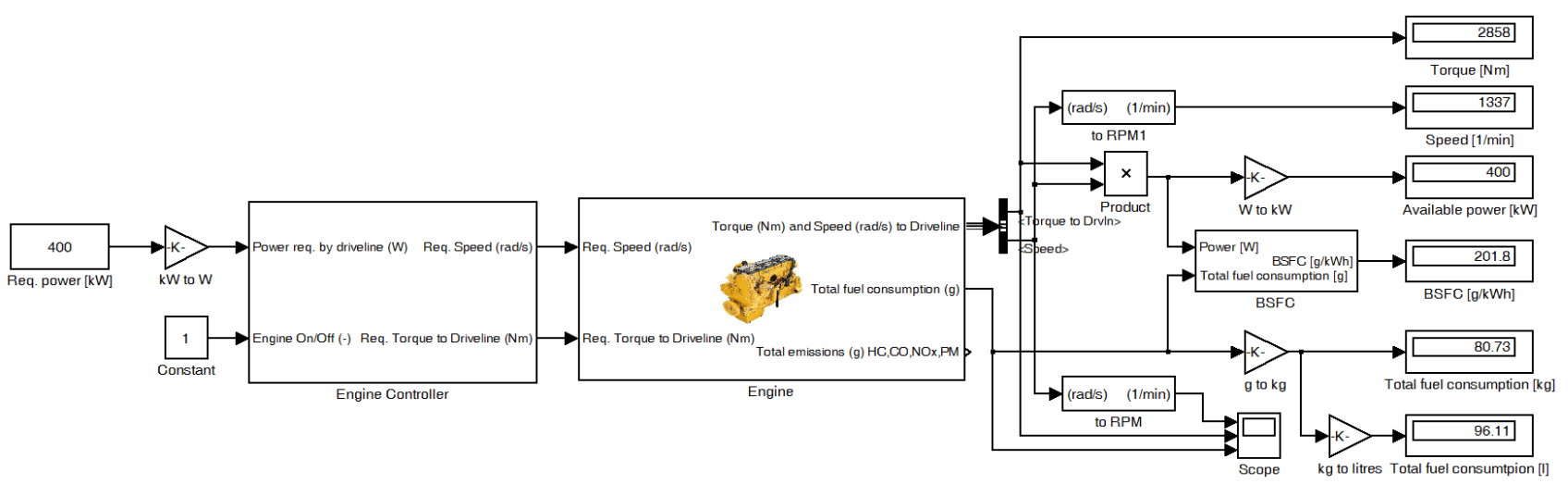

Fig. 8 Combustion Engine model with Engine Controller during testing.

\section{Combustion Engine Model}

The combustion engine is on the top of the simulation model. It is a primary power source. The model provides torque and speed (i.e. power) that can deliver to traction generator at every instant and fuel consumption. The engine model have the Required torque to driveline and Required speed inputs for easy integration to the simulation model. Both inputs represent the power demand, i.e. the required input power to the component connected to the engine (traction generator for example). It is an opposite direction of calculation then usually. Usually speed is an independent variable that is calculated according to the engine torque and load torque. In the represented type of the model the required speed is an independent variable, the engine torque and actual speed are otuputs. If the engine has enough power, new engine speed is equal to the requested speed at the actual simulation step. If not, new engine speed is lower than the requested speed at the actual simulation step.

The engine model is not equipped with one input called Required power in order to separate the control logic from the engine model. Selection of the optimum speed and torque for the required power is calculated in the Engine Controller block. Situation is visible in Fig. 8.

Properties of the engine model:

- Fast transients are not modeled.

- The model is constructed in such a way that only a few parameters from manufacturer are required:

- Nominal parameters - weight, displacement, bore, stroke, number of cylinders, moment of inertia of rotating parts, idle speed.

- Maps - maximum torque or power curve, brake specific fuel consumption at every operating point (torque vs. speed)

- Fuel consumption is calculated from the look-up table according to the engine torque and speed.

- Engine friction losses are modeled from bore, stroke, boost factor and speed to better simulation of engine behaviour if speed is falling. Empirical equation is used [7].

- Engine efficiency can be calculated from the input data (Fig. 10).
See [1] or [2] for more information.

Calculation steps at each simulation step:

1. Required speed limitation to the engine speed range.

2. Dynamic torque calculation.

3. Effective engine torque calculation and dynamic torque limitation.

4. Load torque (available torque to driveline) and actual speed calculation.
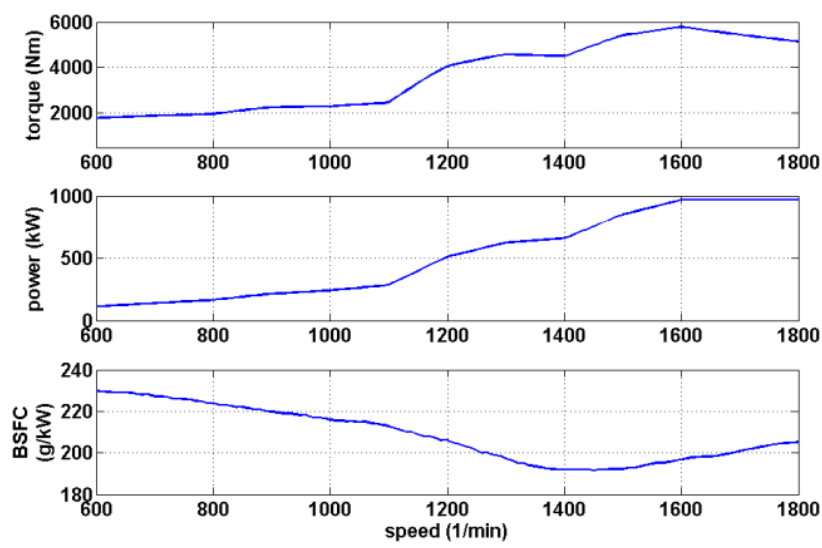

Fig. 9 Torque, power and specific fuel consumption curves of C3508B engine.

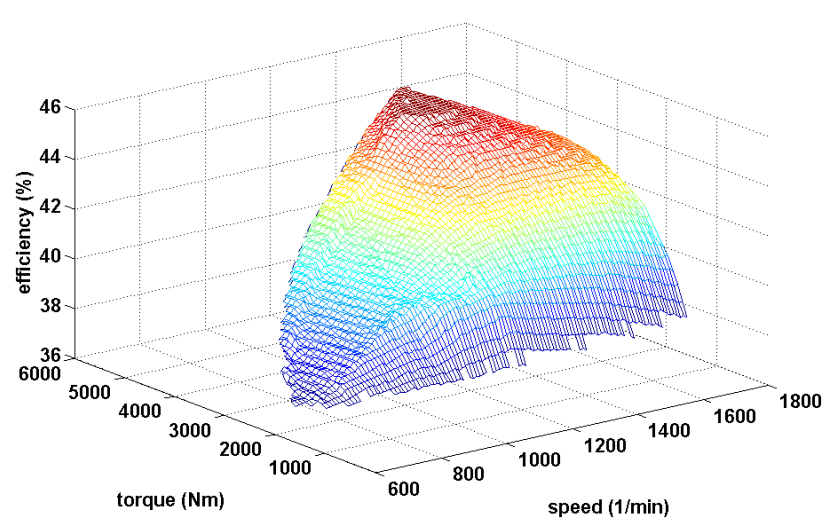

Fig. 10 Efficiency map of the C3508B engine. 
Dynamic torque is calculated as:

$$
\text { Req.Dynamic Torque }(k)=J \cdot \frac{\text { Req.speed }(k)-\operatorname{Speed}(k-1)}{t(k)-t(k-1)}
$$

where $t$ is the simulation time and $J$ is the engine inertia including connected load.

The engine torque is calculated as follows.

The maximum engine torque from the look-up table:

$$
\operatorname{MaxTorque}(k)=f(\operatorname{Speed}(k-1))
$$

The engine friction torque from the look-up table:

$$
\text { FrictionTorque }(k)=f(\operatorname{Speed}(k-1))
$$

The engine torque upper limitation:

Torque $1(k)=$ Req.TorqueToDriveline $(k)+$ Dyn.Torque $(k)$

$$
\operatorname{Torque} 2(k)=\min (\operatorname{Torque} 1(k), \operatorname{MaxTorque}(k))
$$

The engine torque lower limitation (to friction torque):

$$
\text { Torque } 3(k)=\max (\text { Torque } 2(k), \text { FrictionTorque }(k))
$$

The limited engine torque:

$$
\text { Limited EngineTorque }(k)=\text { Torque3 }(k)
$$

The dynamic part of the engine torque is proportionally limited if the engine torque was limited. If it would not be limited, then the whole engine torque would be used as the dynamic torque and torque delivered to the driveline (traction generator) would be zero.

$$
\text { Dyn.Torque }(k)=\text { Req.DynamicTorque }(k) \cdot \frac{\text { Limited EngineTorque }(k)}{\operatorname{Torque}(k)}
$$

In case of models that use the required torque not speed is the dynamic torque calculated naturally as difference between the engine torque and load torque and the speed is calculated from acceleration given by the dynamic torque and moment of inertia. In case of the proposed engine model, where the required speed is input, the dynamic torque is calculated as difference between the required speed and last engine speed. The dynamic torque could be high if the required speed changes fast. The dynamic torque takes precedence in the proposed engine torque calculation in order to let the engine reach the desired speed. Available torque to the driveline (load torque - torque for the traction generator for example) during acceleration could be lowered if limitation occurs. The Engine Control block has to ensure slow enough changes of the required speed (desired power is ramped).

Torque to the driveline (load torque) and speed calculation:

Torque to Drv $\ln (k)=$ Limited Eng.Torque $(k)-$ Limited Dyn.Torque $(k)(9)$

$$
\operatorname{Speed~}(k)=\frac{\text { Limited Dyn.Torque }(k) \cdot(t(k)-t(k-1))}{J}+\operatorname{Speed}(k-1)
$$

\section{Combustion Engine Control Model}

A purpose of the Engine Control block is to select optimum torque and speed combination for the combustion engine according to the reguired power to the driveline (power demand from the traction generator) and to switch the engine on and off. The internal structure of the block is in Fig. 11.

The required power is ramped. The optimum speed is determinted from the ramped power using the look-up table. The optimum speed curve is created from the brake specific consumption map (minimum speed for every power is found) or adopted from manufacturer if available, Fig. 12. The torque demand is calculated from the speed and power demands. The logic input Engine On/Off can be used to start or stop the engine. The engine start is modelled very simply and does not correspond to reality well. Start is very fast with full torque available at the idle speed, the engine starter is not modelled. After the engine stop it is required the torque and speed demands are set to zero, the engine speed is falling according to friction losses and inertia.

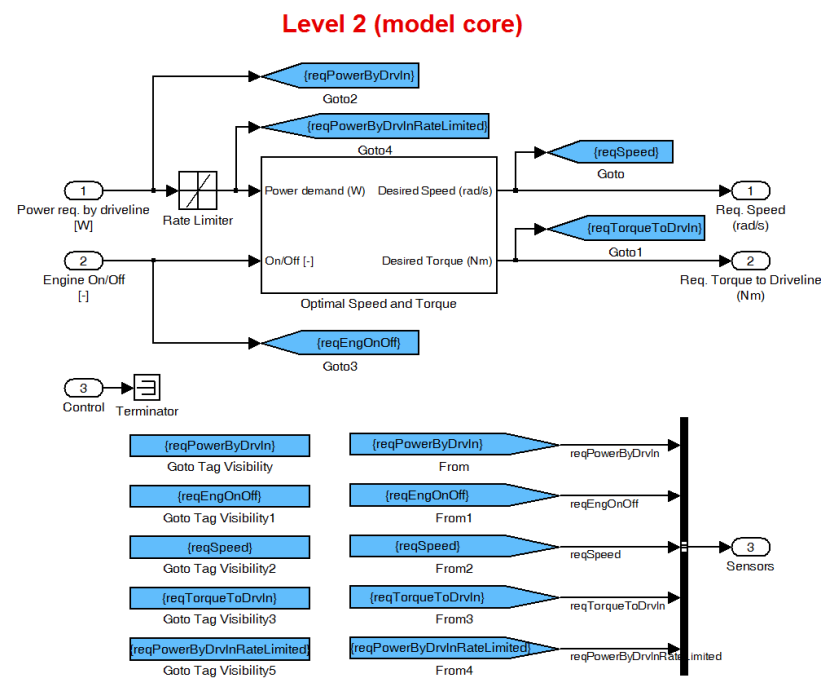

Fig. 11 Internal structure of the Engine Controller block.

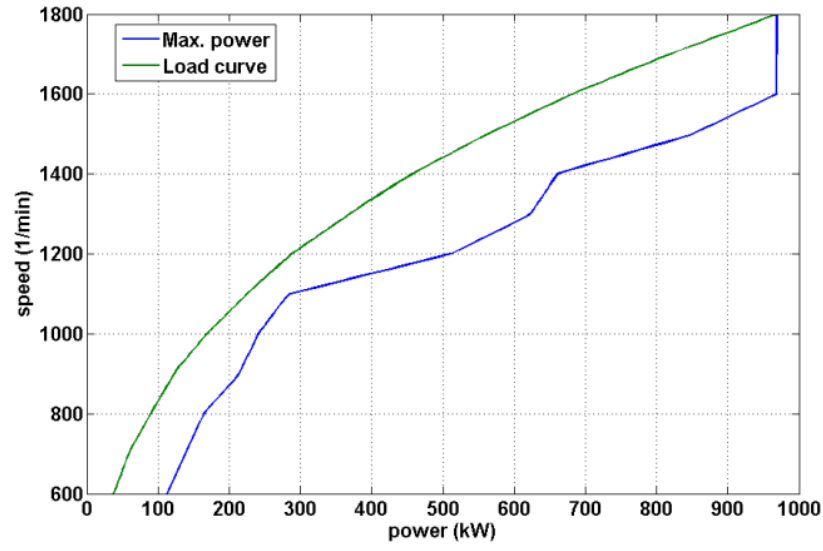

Fig. 12 Load curve for the C3508B engine.

\section{E. Testing of Combustion Engine Model}

The engine model and Engine Control model were tested at steady state and during transients. The test model can be seen in Fig. 8. Fuel consumption calculated by the model was compared to the manufacturer data at steady state. The Caterpillar C3508B $(970 \mathrm{~kW})$ engine with the 
load curve shown in Fig. 12 was used. The load curve was adopted from manufacturer because the fuel consumption data at ten operating points on the load curve were available from manufacturer. The fuel consumption in litres per hour calculated by the model differs from the manufacturer data at most by $2 \%$ in the whole range of the load curve. The error can originate from the fuel map data processing and interpolation in the look-up table. Manufacturer itself declares 5\% error in the fuel consumption measurement and $3 \%$ error in the power measurement.

There were four engine models created up to now. All engine models were tested and are ready to use.

TABLE I.

LIST OF CREATED ENGINE MODELS

\begin{tabular}{|c|c|c|c|c|}
\hline & $\begin{array}{c}\text { CAT } \\
\text { 3508B }\end{array}$ & $\begin{array}{c}\text { CAT C27 } \\
\text { STAGE } \\
\text { IIIA } \\
709 \text { kW } \\
\end{array}$ & $\begin{array}{c}\text { CAT C15 } \\
\text { STAGE } \\
\text { IIIB } \\
403 \text { kW } \\
\end{array}$ & $\begin{array}{c}\text { TEDOM } \\
\text { TD242 }\end{array}$ \\
\hline $\begin{array}{c}\text { Nominal } \\
\text { power }(\mathrm{kW})\end{array}$ & 970 & 709 & 403 & 242 \\
\hline $\begin{array}{c}\text { Nominal } \\
\text { speed }\left(\mathrm{min}^{-1}\right)\end{array}$ & 1800 & 1800 & 2100 & 1950 \\
\hline $\begin{array}{l}\text { Idle speed } \\
\left(\min ^{-1}\right)\end{array}$ & 600 & 600 & 600 & 650 \\
\hline $\begin{array}{c}\text { Idle fuel } \\
\text { consumption } \\
(\mathrm{lit} / \mathrm{h})\end{array}$ & 4,5 & N/A & N/A & N/A \\
\hline $\begin{array}{l}\text { Weight (kg) } \\
(\text { dry + fill) }\end{array}$ & $4582+343$ & $2946+136$ & $2113+65$ & $970+56.5$ \\
\hline $\begin{array}{c}\text { Displacement } \\
\left(\mathrm{dm}^{3}\right)\end{array}$ & 34.5 & 27.03 & 15.2 & 11.946 \\
\hline Stroke $(\mathrm{mm})$ & 190 & 152,4 & 171 & 150 \\
\hline Bore $(\mathrm{mm})$ & 170 & 137,2 & 137 & 130 \\
\hline Cylinders (-) & 8 & 12 & 6 & 6 \\
\hline $\begin{array}{c}\text { Boost factor } \\
(-)\end{array}$ & $\begin{array}{c}2 \\
\text { (estimated) }\end{array}$ & $\begin{array}{c}2 \\
\text { (estimated) }\end{array}$ & $\begin{array}{c}2 \\
\text { (estimated) }\end{array}$ & 1.7 \\
\hline Inertia $\left(\mathrm{kgm}^{2}\right)$ & $\begin{array}{c}1.5 \\
\text { (estimated) }\end{array}$ & $\begin{array}{c}1 \\
\text { (estimated) }\end{array}$ & $\begin{array}{c}0.75 \\
\text { (estimated) }\end{array}$ & $\begin{array}{c}0.5 \\
\text { (estimated) }\end{array}$ \\
\hline
\end{tabular}

\section{F. Battery Model}

Lithium Titan Oxide (Li4Ti5O12) batteries were selected according to literature search. LTO batteries deliver high charge/discharge currents (5-6C) and have a high power to weight ratio. In case of the electric hybrid drive less powerful diesel engine was selected (CAT C15 $403 \mathrm{~kW}$ ) and smaller traction generator. Weight savings was $4629 \mathrm{~kg}$ comparing to the $970 \mathrm{~kW}$ dieselelectric locomotive 744. It enables installation of batteries with a total capacity $416 \mathrm{kWh}(90 \mathrm{kWh} / \mathrm{ton})$. The final capacity was reduced to $200 \mathrm{kWh}$ due to room considerations and installation of the battery management. It was assumed that energy recuperation is disabled for a speed below $10 \mathrm{~km} / \mathrm{h}$.

The battery is connected directly do the DC-bus without converter. The basic input to the Battery block is the power demand. The output from the Battery block is the available power that the battery can deliver to the DC-bus in case of discharging or receive from the DC-bus in case of charging. Additional information like state of charge is linked to the Sensors tag to be available in other parts of the simulation model and is also logged. See Fig. 13.
Level 1

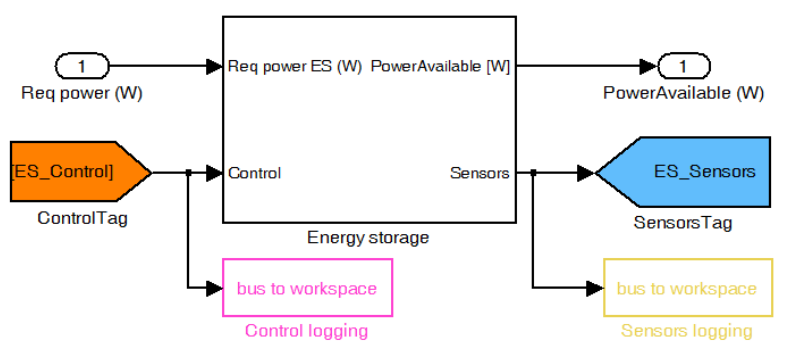

Fig. 13 Battery block.

The battery model requires these parameters: number of cells, nominal cell capacity, nominal cell voltage, internal resistance, allowed depth of discharge, charging power, discharging power.

The maximum acceptable charge/discharge current depends on the required power and battery state of charge. Calculations are different during charging and discharging.

The battery voltage and current are calculated by an iterative algorithm using equations below. Equation (11) was developed from experimental measurements made on LiFePO4 batteries (3,2 V / 40 Ah, Winston Battery, type LFP40AHA) at our department.

$$
\begin{gathered}
U_{b a t}=-0,0016 \cdot n \cdot\left(100-\left(\frac{E_{b a t}}{\mathrm{C}_{b a t}} \cdot 100\right)\right)+n \cdot U_{c e l l}-n \cdot R_{i c e l l} \cdot I_{b a t} \\
I_{b a t}=\frac{\mathrm{P}_{r e q}}{U_{b a t}}
\end{gathered}
$$

Where:

$$
\begin{aligned}
& \mathrm{U}_{\text {bat }}-\text { battery voltage at the required power }(\mathrm{V}) \\
& \mathrm{n}-\text { number of cells } \\
& \mathrm{E}_{\text {bat }}-\text { energy stored in battery }(\mathrm{Wh}) \\
& \mathrm{C}_{\text {bat }}-\text { battery capacity }(\mathrm{Wh}) \\
& \mathrm{U}_{\text {cell }}-\text { cell voltage }(\mathrm{V}) \\
& \mathrm{R}_{\text {icell }}-\text { cell internal resistance }(\Omega) \\
& \mathrm{I}_{\text {bat }}-\text { available current for the required power and voltage }(\mathrm{A}) \\
& \mathrm{P}_{\text {req }}-\text { required power }(\mathrm{W})
\end{aligned}
$$

The required power is limited according to the battery state of charge in order to prevent deep discharge. In each simulation step the energy change is calculated and integrated to get the battery state of charge. The initial state of charge at the start of simulation can be set in the initialization file or in mask of block.

Behaviour of the battery model can be seen in Figs. 14 and 15. The green curve in Fig. 14 is the power demand that is higher than the battery can deliver. The decreasing available power can be seen during the power limitation because the battery is discharging (stored energy decreases). In the right part of figure the battery charging occurs. As in the discharging phase, the charging power is limited according to the permissible charging current. Energy, that the battery cannot absorb, is lost in an electrodynamic braking resistor or mechanical brakes. The battery voltage and current during discharging and charging can be seen in Fig. 15. 


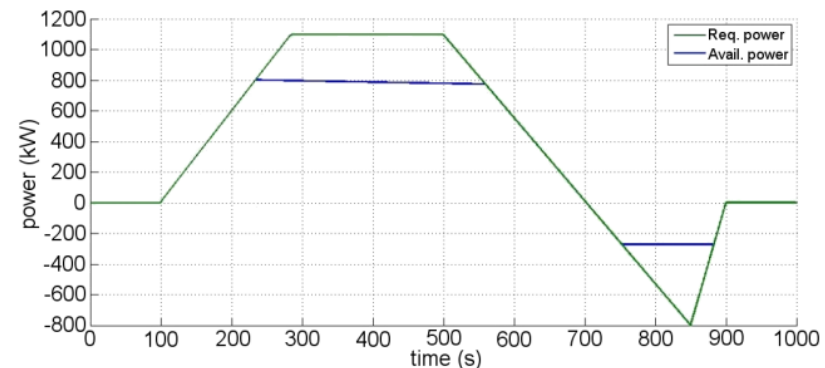

Fig. 14 Required and available battery power.

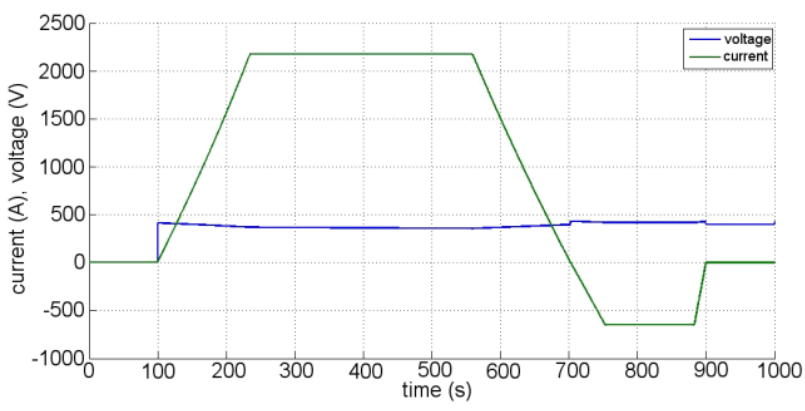

Fig. 15 Battery voltage and current.

\section{G. Traction Motor Model}

The traction motor block converts electric power to mechanical power. Analytical equations are used for the input/output power relationship.

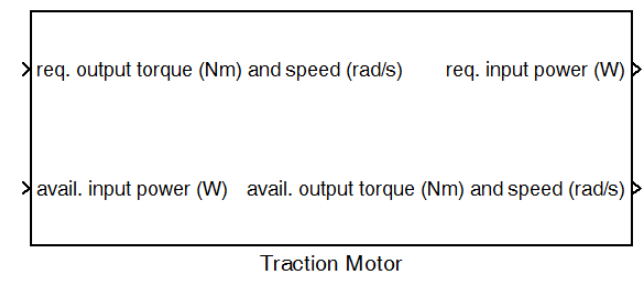

Fig. 16 Traction motor block.

Inputs:

- $\quad$ required output torque $(\mathrm{Nm})$

- $\quad$ required speed $(\mathrm{rad} / \mathrm{s})$

- available input electric power (W)

- number of motors, DC-bus voltage (hidden terminal)

Outputs:

- $\quad$ required input electric power $(\mathrm{W})$

- available output torque $(\mathrm{Nm})$

- $\quad$ available output speed $(\mathrm{rad} / \mathrm{s})$

The shunting locomotive model is based on the shunting locomotive 744. The Locomotive 744 is equipped with four asynchronous traction motors with the power output $366 \mathrm{~kW}$ each. The torque curve of the TAM 1084 C6 traction motor is shown in Fig. 17.

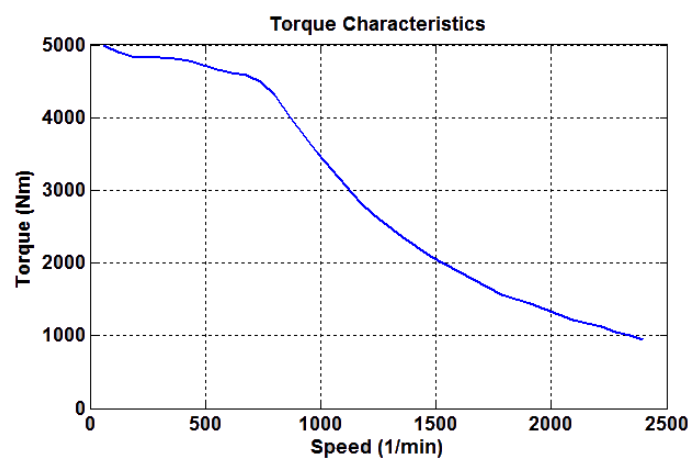

Fig. 17 Torque curve of the traction motor TAM 1084 C6.

The traction motor model was designed in such a way that only basic parameters of the motor are required for the model setup while keeping good model accuracy. This topic was already discussed in section A.

In case of traction motors and batteries constant efficiency cannot be used because losses strongly depend on the operating point. Well known general behavior of the said components can be used to determine losses and efficiencies with reasonable accuracy using only a few basic parameters that are available in datasheets. In the following text equations describing the traction motor model are presented. Derivation of following equations is presented in [5].

Used simplification:

- Linear relationship between current and torque.

- Losses in magnetic circuit prevail mechanical losses (mechanical losses are neglected).

- No-load losses depend linearly on speed and quadraticaly on voltage.

- Constant winding resistance.

The forward path (from motor to DC-bus) is modelled as follows. The goal is to determine the input electric power with torque and speed and DC-bus voltage as inputs.

Input electric power $P_{e l}$ :

$$
P_{e l}=P+\Delta P
$$

$$
P_{e l}=M \cdot \omega_{m}+\Delta P_{0 n} \cdot\left(\frac{U_{1}}{U_{1 n}}\right)^{2} \cdot \frac{\omega_{m n}}{\omega_{m}}+\Delta P_{j n} \cdot\left(\frac{M \cdot \omega_{m} \cdot U_{1 n}}{M_{n} \cdot \omega_{m n} \cdot U_{1}}\right)^{2}
$$

The backward path (from motor to transmission) is modelled as follows. The goal is to determine the output mechanical power with electric power, speed and DC-bus voltage as inputs.

Equation (14) arranged as quadratic equation:

$$
P_{e l}-\Delta P_{0 n} \cdot\left(\frac{U_{1}}{U_{1 n}}\right)^{2} \cdot \frac{\omega_{m n}}{\omega_{m}}-P-\Delta P_{j n} \cdot\left(\frac{U_{1 n}}{P_{n} \cdot U_{1}}\right)^{2} \cdot P^{2}=0
$$

No-load losses:

$$
\Delta P_{0}=\Delta P_{0 n} \cdot\left(\frac{U_{1}}{U_{1 n}}\right)^{2} \cdot \frac{\omega_{m n}}{\omega_{m}}
$$

The output mechanical power: 


$$
P_{1,2}=\frac{1 \pm \sqrt{1+4 \cdot\left(P_{e l}-\Delta P_{0}\right) \cdot \Delta P_{j n} \cdot\left(\frac{U_{1 n}}{P_{n} \cdot U_{1}}\right)^{2}}}{-2 \cdot \Delta P_{j n} \cdot\left(\frac{U_{1 n}}{P_{n} \cdot U_{1}}\right)^{2}}
$$

In case of recuperation $P_{e l}$ is negative and the signs differ in Eq. (15) and (17):

$$
\begin{gathered}
P_{e l}+\Delta P_{0 n} \cdot\left(\frac{U_{1}}{U_{1 n}}\right)^{2} \cdot \frac{\omega_{m n}}{\omega_{m}}+P+\Delta P_{j n} \cdot\left(\frac{U_{1 n}}{P_{n} \cdot U_{1}}\right)^{2} \cdot P^{2}=0 \\
P_{1,2}=\frac{1 \pm \sqrt{1-4 \cdot\left(P_{e l}-\Delta P_{0}\right) \cdot \Delta P_{j n} \cdot\left(\frac{U_{1 n}}{P_{n} \cdot U_{1}}\right)^{2}}}{2 \cdot \Delta P_{j n} \cdot\left(\frac{U_{1 n}}{P_{n} \cdot U_{1}}\right)^{2}}
\end{gathered}
$$

Valid value of $P_{1,2}$ is the one with minus sign in front of the square root.

The terminal voltage $U_{l}$ is calculated as

$$
U_{1}=\frac{U_{1 n}}{\omega_{n}} \cdot \omega
$$

and limited to the motor nominal terminal voltage or to maximum terminal voltage according to the DC-bus voltage whichever is smaller. This limitation represents field the weakening part of the U/f relationship.

Total losses at the nominal operating point are calculated as:

$$
\Delta P_{n}=P_{e l n}-P_{n}=\sqrt{3} \cdot U_{1 n} \cdot I_{1 n} \cdot \cos \phi_{n}-P_{n}
$$

The nominal Joule losses and no-load losses are calculated as percent parts of the total nominal power loss.

$$
\begin{aligned}
& \Delta P_{j n}=0,6 \cdot \Delta P_{n} \\
& \Delta P_{0 n}=0,4 \cdot \Delta P_{n}
\end{aligned}
$$

Losses can be calculated more precisely if the stator winding resistance and transformed rotor winding resistance are known, Eq. (23) and (24).

$$
\begin{gathered}
\Delta P_{j n}=3 \cdot\left(R_{1}+R_{2}^{\prime}\right) \cdot I_{1 n}^{2} \\
\Delta P_{0 n}=\Delta P_{n}-\Delta P_{j n}
\end{gathered}
$$

The temperature dependent resistance can also be applied in Eq. (23).

Legend:

$\mathrm{P}$ - output mechanical power (W)

$\mathrm{P}_{\mathrm{n}}-$ nominal output mechanical power $(\mathrm{W})$

$\mathrm{P}_{\mathrm{el}}-$ input electric power $(\mathrm{W})$

$\mathrm{P}_{\text {eln }}-$ nominal input electric power $(\mathrm{W})$

$\Delta \mathrm{P}_{0}-$ no-load losses $(\mathrm{W})$

$\Delta \mathrm{P}_{0 \mathrm{n}}-$ nominal no-load losses $(\mathrm{W})$

$\Delta \mathrm{P}_{\mathrm{j}}-$ Joule losses $(\mathrm{W})$

$\Delta \mathrm{P}_{\mathrm{jn}}-$ nominal Joule losses $(\mathrm{W})$

$\Delta \mathrm{P}_{\mathrm{n}}-$ nominal total losses $(\mathrm{W})$

$\omega-$ mechanical speed $(\mathrm{rad} / \mathrm{s})$

$$
\begin{aligned}
& \omega_{\mathrm{n}}-\text { nominal mechanical speed }(\mathrm{rad} / \mathrm{s}) \\
& \mathrm{U}_{1}-\text { terminal voltage }(\mathrm{V}) \\
& \mathrm{U}_{1 \mathrm{n}}-\text { nominal terminal voltage }(\mathrm{V}) \\
& \mathrm{I}_{1 \mathrm{n}}-\text { nominal phase current }(\mathrm{A}) \\
& \cos \phi_{\mathrm{n}}-\text { nominal power factor }(-)
\end{aligned}
$$

The efficiency map calculated from the introduced equations of the used traction motor is shown in Fig. 18.

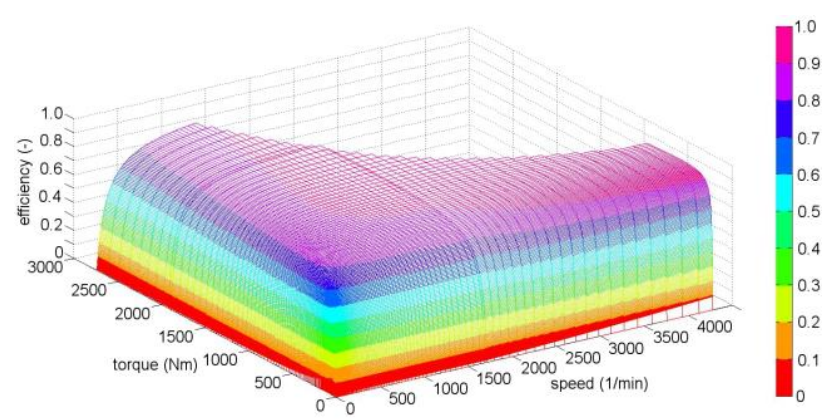

Fig. 18 Efficiency map of the $340 \mathrm{~kW}$ traction motor TAM 1084 C6.

\section{H. Traction Generator Model}

The PMSG connected to a diesel engine was selected as a source of electric power in the hybrid locomotive. The generator power and size was reduced according to the selected diesel engine $(403 \mathrm{~kW})$. The mass reduction enables installation of more batteries. Parameters of the selected PMSG are written in TABLE II.

TABLE II.

PARAMETERS OF TRACTION GENERATOR

\begin{tabular}{|c|c|}
\hline Manufacturer & TES Vsetín \\
\hline Type & GSV 280 \\
\hline Nominal voltage (V) & 400 \\
\hline Nominal current (A) & 722 \\
\hline Nominal power (kW) & 400 \\
\hline Nominal power (kVA) & 500 \\
\hline Nominal speed (min $\left.{ }^{-1}\right)$ & 1500 \\
\hline Efficiency (\%) & 95 \\
\hline Power factor (-) & 0.8 \\
\hline Inertia $\left(\mathrm{kgm}^{2}\right)$ & 7.7 \\
\hline
\end{tabular}

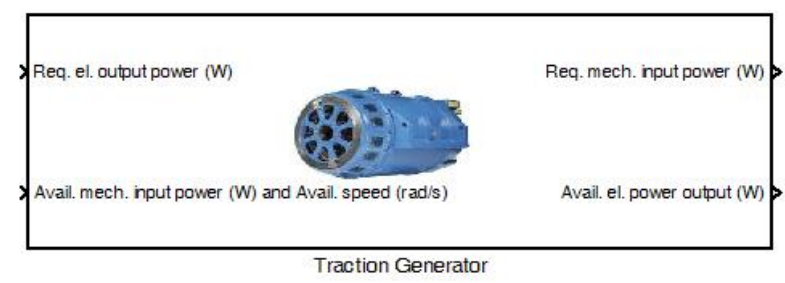

Fig. 19 Traction generator block.

Inputs:

- required output elelectric power (W)

- available input mechanical power (W)

- available input mechanical speed ( $\mathrm{rad} / \mathrm{s})$

Outputs:

- $\quad$ required input mechanical power (W)

- available output electric power (W) 
The main purpose of model is to calculate the input mechanical power for the required electric power and the output electric power for the available input mechanical power. The input mechanical power to the traction generator is supplied by the diesel engine. The torque is positive if the generator acts as a source of electric power. The torque is negative if the generator acts as a motor.
Behavior of the traction generator is described in the same manner as in the traction motor model. The same simplification is used. The U/f ratio is kept constant. The field weakening is not used and the generator is operating all the time over $40 \%$ of the nominal speed (idle speed of the diesel engine is $600 \mathrm{rpm}$ ).

Level 2 (model core)

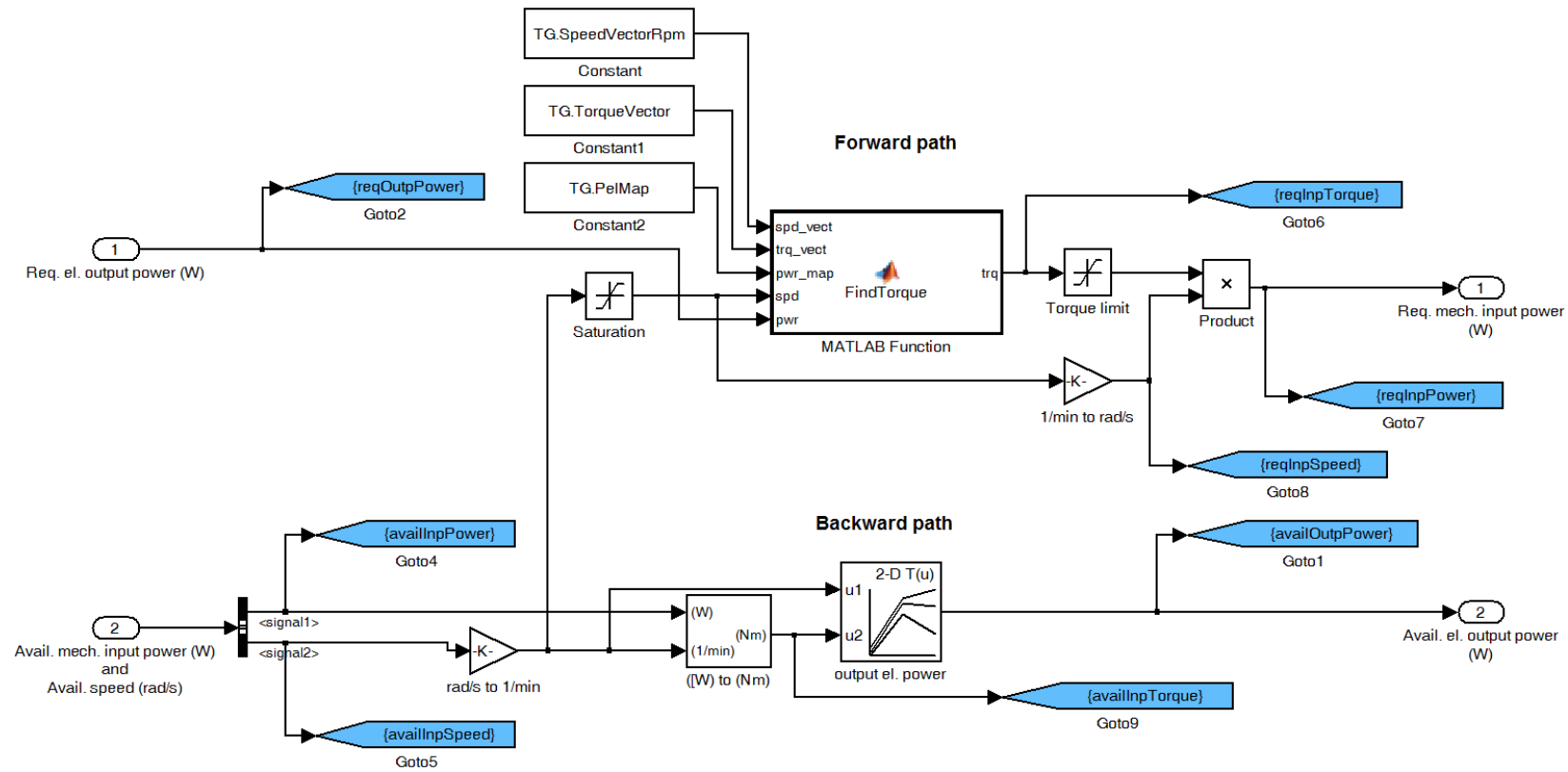

Fig. 20 Internal structure of the traction generator block (Control and Sensors terminals are not shown due to figure size).

The nominal no-load and Joule losses are calculated as $50 \%$ ratio of the total nominal power loss.

$$
\begin{aligned}
& \Delta P_{0 n}=0.5 \cdot \Delta P_{n} \\
& \Delta P_{j n}=0.5 \cdot \Delta P_{n}
\end{aligned}
$$

The nominal total loss:

$$
\Delta P_{n}=P_{n}-P_{e l n}=M_{n} \cdot \omega_{n}-\sqrt{3} \cdot U_{1 n} \cdot I_{1 n} \cdot \cos \phi_{n}
$$

The total loss at any operating point:

$$
\Delta P=\Delta P_{0 n} \cdot\left(\frac{\omega}{\omega_{n}}\right)-\Delta P_{j n} \cdot\left(\frac{M}{M_{n}}\right)^{2}
$$

The output electric power:

$$
\begin{gathered}
P_{e l}=P-\Delta P \\
P_{e l}(\omega, M)=\omega \cdot M-\Delta P_{0 n} \cdot\left(\frac{\omega}{\omega_{n}}\right)-\Delta P_{j n} \cdot\left(\frac{M}{M_{n}}\right)^{2}
\end{gathered}
$$

The efficiency:

$$
\eta(\omega, M)=\frac{P_{e l}}{P}
$$

The $\mathrm{P}_{\mathrm{el}}$ and efficiency maps are calculated before the model is runing.

The map inversion is done in order to calculate the mechanical power input in the opposite path (i.e. from electrical side to mechanical side). The functional dependency $M=f\left(\omega, P_{e l}\right)$ is made from $P_{e l}=f(\omega, M)$.

The efficiency map of the traction generator for both quadrants is shown in Fig. 21.

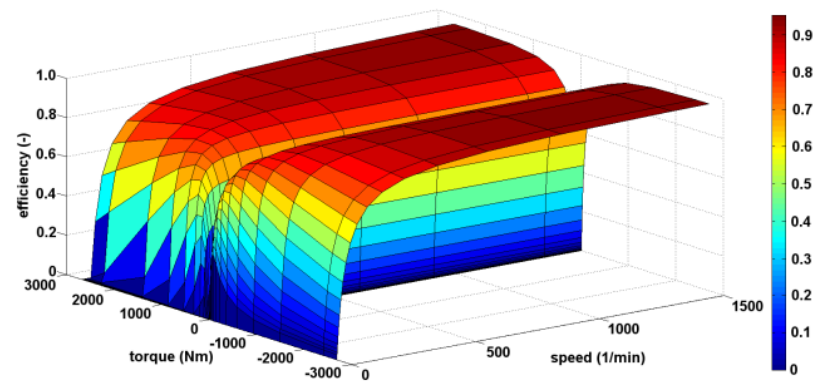

Fig. 21 Efficiency map of the traction generator

However the diesel engine starting from traction generator is not implemented yet because the diesel engine model does not support this feature.

A nominal generator speed doesn't match diesel engine speed at maximum power. Although generator nominal speed is $1500 \mathrm{~min}^{-1}$ the diesel engine can operate up to its 
maximum power at maximum speed (1800 or $\left.2200 \mathrm{~min}^{-1}\right)$. There is no change in calculations of power losses. Requested mechanical input and available electrical output in generator model are calculated in the manner described in this section.

\section{Auxiliary Consumption Model}

The auxiliary consumption block calculates electric energy consumption of the locomotive auxiliary components. The auxiliary consumption is not constant in real world. In the model it would be calculated according to operating conditions. An inaccurate calculation of auxiliary consumption can strongly influence simulation results especially at times where the traction power is low.

Main consumers are: traction motors cooling, diesel engine cooling, air compressor, $24 \mathrm{~V}$ electric grid.

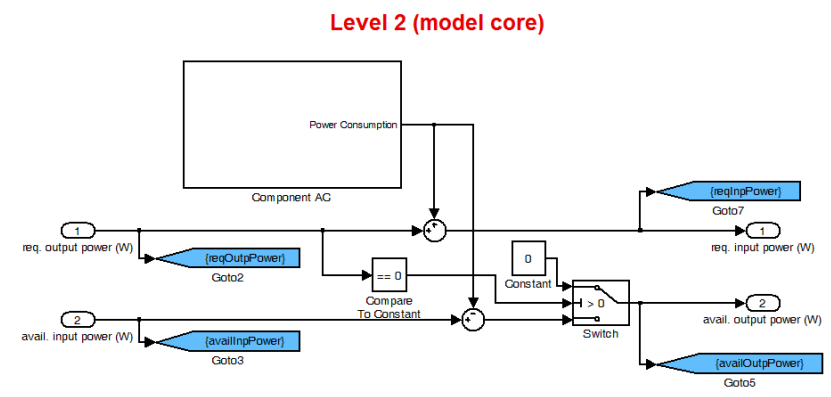

Fig. 22 Internal structure of the auxiliary consumption block.

The auxiliary consumption block is placed between the traction motor AC/DC converter block and DC-bus block (Fig. 3).

It adds an electric power demand to the power demand from the traction motor. In the opposite path the power delivered from the DC-bus to the traction motors is lowered by the auxiliary consumption.

At first version of the simulation model the auxiliary consumption calculation was replaced with a constant mean power consumed by the auxiliary devices. However simulation results showed big difference to real world. New algorithm is developing in order to calculate the auxiliary consumption more accurate. For example the air compressor switching will be based on the calculated pressure in the air reservoir according to degree of braking and number of coaches.

\section{J. Mechanical Brakes Model}

This block ensures that the desired brake power will be achieved if the negative desired power (force) is commanded. The priorities during braking are:

1. Battery charging.

2. Electrodynamic brake activation if battery cannot absorb such amount of energy.

3. Mechanical brake is activated if above consumers reached their limits.

If the mechanical brakes would not be activated, the vehicle would not be able to stop at a defined place on the track. The brakes are controlled in such manner that train will reach defined speed with defined acceleration/deceleration. Some kind of a simple automatic train control is used.

\section{K. Vehicle Model}

This block calculates the required tractive force and speed according to the drive cycle and real speed according to the available tractive force. Calculations are based on the basic equations describing the train movement (for example rolling and grade resistance of the train are computed).

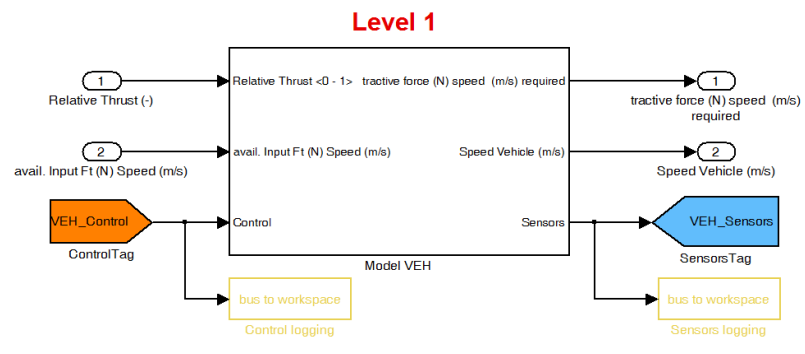

Fig. 23 Vehicle block.

The block is parametrized by: locomotive weight, coach weight, number of coaches, number of wheels, maximum speed, specific resistances, tractive effort curve etc.

The forward path (from drive cycle to transmission) is described first. The tractive effort is calculated from the relative thrust (in the range from -1 to +1 ) and tractive effort curve (in $\mathrm{kN}$ ) according to the train speed. Next the train rolling resistance and grade resistance are calculated. The dynamic force is calculated as a difference between the tractive effort and rolling plus grade resistance. The acceleration is calculated and limited to a predefined limit. The inertia force is calculated from the limited acceleration and locomotive and coaches weights including inertia of rotating parts. The total required tractive effort is sum of the tractive effort calculated from the relative thrust with inertia force.

The backward path description follows. Power sources installed in locomotive do not have to have enough power to supply the required tractive effort calculated in the forward path. Therefore the available tractive force can be lower than required. The main goal in the backward path is to calculate the actual train speed according to the available tractive effort and last speed. The resistances, dynamic force and acceleration are calculated in the same manner as in the forward loop. The vehicle speed is calculated from acceleration by integration.

Some equations used in the vehicle block follow.

The rotating mass coefficient is used in the dynamic force calculation:

$$
r_{d}=102 \xi a\left(\frac{N}{k N}\right)
$$

Where:

$$
\begin{aligned}
& r_{d}-\text { specific dynamic force }(\mathrm{N} / \mathrm{kN}) \\
& \xi \text { - rotating mass coefficient } \\
& a \text { - acceleration }\left(\mathrm{ms}^{-2}\right)
\end{aligned}
$$

The rotating component inertia is added to mass of vehicle with help of the rotating mass coefficient. 
TABLE III.

RotATING MASS COEFFICIENT

\begin{tabular}{|c|c|}
\hline Vehicle type & $\begin{array}{c}\text { Rotating mass } \\
\text { coefficient }\end{array}$ \\
\hline Electric locomotive & $1.2-1.3$ \\
\hline Railcar & $1.2-1.25$ \\
\hline Passenger coach & $1.05-1.06$ \\
\hline Freight car & $1.04-1.12$ \\
\hline
\end{tabular}

The train acceleration:

$$
a=\frac{F_{a}-F_{R}}{\frac{102 \cdot g}{1000}\left(\zeta_{l o c} \cdot m_{l o c}+\zeta_{w a g} \cdot m_{\text {wag }}\right)}
$$

Where:

$a$ - acceleration $\left(\mathrm{ms}^{-2}\right)$

$F_{a}-$ available tractive effort $(\mathrm{N})$

$F_{R}-$ resistance force $(\mathrm{N})$

$\zeta_{\text {loc }}$ - rotating mass coefficient of locomotive (-)

$\zeta_{w a g}$ - rotating mass coefficient of wagons (-)

$m_{\text {loc }}-$ locomotive weight $(\mathrm{kg})$

$m_{\text {wag }}-$ sum of weight of all wagons $(\mathrm{kg})$
The train speed:

$$
v(k)=v(k-1)+a(k) \cdot d t
$$

Where:

$$
\begin{aligned}
& v(k)-\text { actual train speed }\left(\mathrm{ms}^{-1}\right) \\
& v(k-1)-\text { train speed at previous simulation step }
\end{aligned}
$$
$\left(\mathrm{ms}^{-1}\right)$

$a$ - actual acceleration $\left(\mathrm{ms}^{-2}\right)$

$d t$ - length of simulation step (s)

\section{SiMULATIONS}

This section describes simulations of the hybrid electric shunting locomotive and analyses simulation results. Simulations were performed in order to analyze the hybrid locomotive in shunting duty.

\section{A. Duty Types}

There were eight types of typical duties created for simulation purposes: shunting duty at siding rail (No.1), shunting duty in storehouse (No.2), shunting duty at feed hopper (No.3, No.4), sorting coaches on shunting yard (No.5, No.6), moving train set around railway station (No.8), washstand for coaches (No.7). Duties differ mainly by train weight, length and number of stops (Fig. 24,25 and 26).
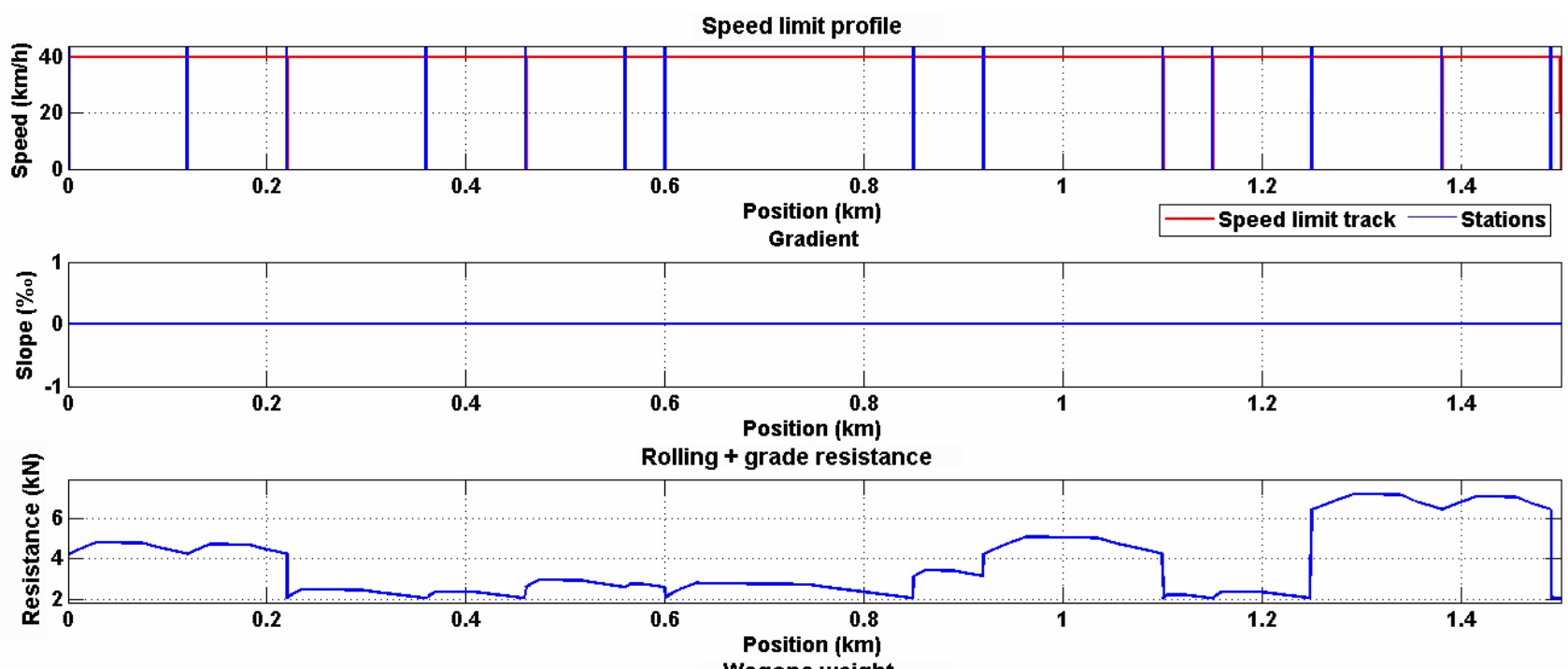

Wagons weight

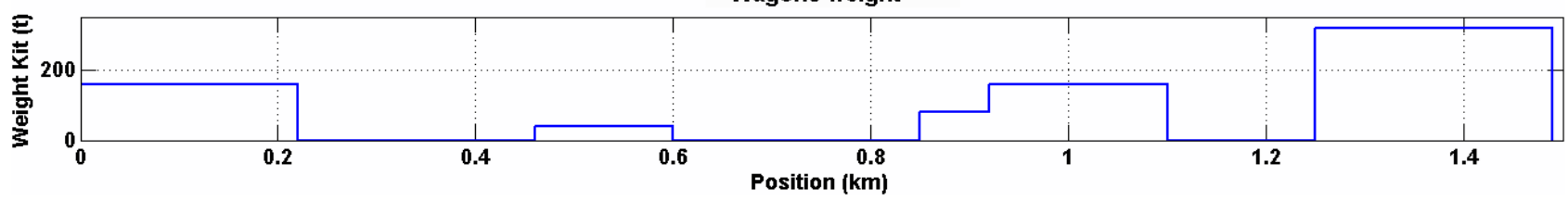

Fig. 24 Duty number 5 (sorting coaches on shunting yard). 


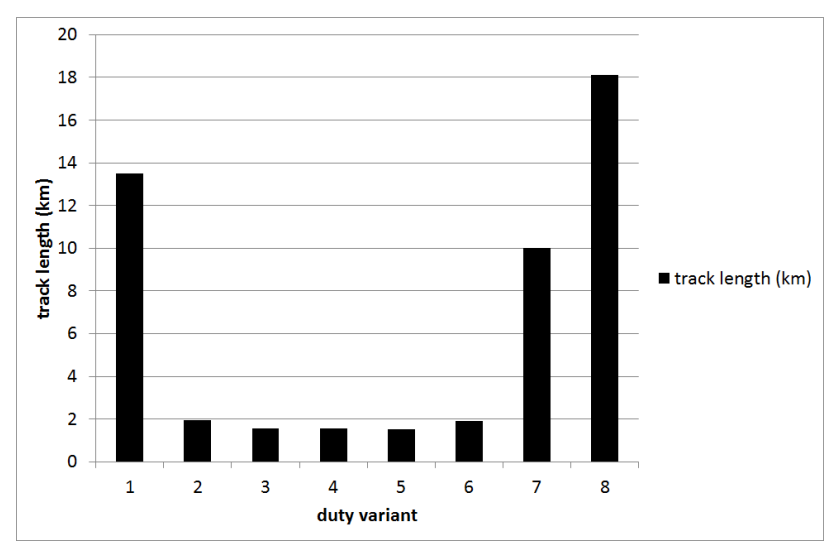

Fig. 25 Track lengths.

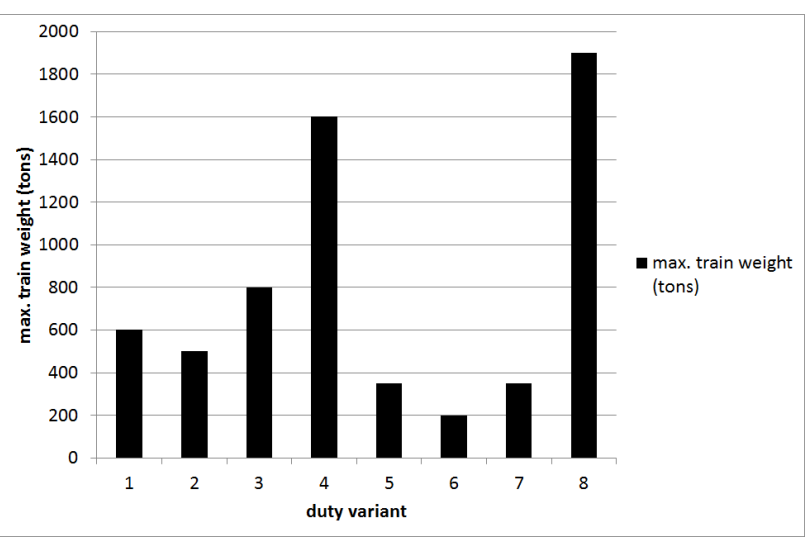

Fig. 26 Maximum train weight.

The shunting duty type number five was selected as a reference. In the shunting duty number five the locomotive makes shunting movement of couches on shunting yard. The drive cycle is shown in Fig. 24. All quantities shown in Fig. 24 are distance dependent.

Speed profile is shown on top of Fig. 24, stations (stops) are marked blue. The track grade is zero (second chart). The third chart from the top shows the sum of rolling and grade resistance of the train (locomotive plus wagons). Total weight of wagons is visible in the bottom chart. Total weight changes as wagons are connected and disconnected from locomotive.

\section{B. Locomotive Types and Hybrid Drive Control Strategy}

There were three types of locomotive created and compared among each other. Locomotives differ from each other by the power source type and control strategy.

TABLE IV

LOCOMOTIVES USED IN SIMULATIONS

\begin{tabular}{|c|c|c|c|}
\hline Variant & $\begin{array}{c}\text { Diesel engine } \\
\text { type }\end{array}$ & $\begin{array}{c}\text { Battery } \\
\text { capacity }\end{array}$ & $\begin{array}{c}\text { Control } \\
\text { strategy }\end{array}$ \\
\hline Diesel (loco 744) & $\begin{array}{c}\text { CAT C3508 } \\
(970 \mathrm{~kW})\end{array}$ & - & - \\
\hline $\begin{array}{c}\text { Hybrid, diesel } \\
\text { preferred }\end{array}$ & $\begin{array}{c}\text { CAT C15 } \\
(403 \mathrm{~kW})\end{array}$ & $200 \mathrm{kWh}$ & $\begin{array}{c}\text { Diesel } \\
\text { preferred }\end{array}$ \\
\hline $\begin{array}{c}\text { Hybrid, battery } \\
\text { preferred }\end{array}$ & $\begin{array}{c}\text { CAT C15 } \\
(403 \mathrm{~kW})\end{array}$ & $200 \mathrm{kWh}$ & $\begin{array}{c}\text { Battery } \\
\text { preferred }\end{array}$ \\
\hline
\end{tabular}

Brief description of variants follows.

Diesel locomotive 744 - reference vehicle. Model of four axle diesel-electric locomotive 744 by CZ Loko brand. The nominal weight is 74 tons. The diesel engine runs 15 minutes at idle after the end of the drive cycle and every time the vehicle stops during shunting. Diesel startstop system is simulated in this manner. The 15 minutes delay represents time to stop engine in order to prevent engine damage and for maintenance before the drive cycle.

Hybrid, diesel preferred - model of the hybridized locomotive 744 with the preferred diesel engine operation. A less powerful engine $(403 \mathrm{~kW})$ and traction alternator (500 kVA) were installed. Saved weight was filled with batteries. The diesel engine is a preferred power source. The batteries deliver power in transients and if the diesel engine has not enough power. The batteries are charging during decelerations and after vehicle stops moving. The batteries are always charged to $95 \%$ nominal capacity before the simulation ends in order to stop simulation with a defined state of charge.

Hybrid, battery preferred - model of the hybridized locomotive 744 with the preferred battery operation. The diesel engine starts and begins to charge battery if the battery state of charge (SOC) is less than $50 \%$. The diesel engine stops if the battery SOC reaches $95 \%$. Simulation stops after the battery SOC reaches $95 \%$.

\section{Graphic Outputs from Simulations}

This section contains graphs from the simulations. Only the results from the simulations in duty type number 5 (sorting coaches on shunting yard) with the drive configuration "Hybrid, diesel preferred" are shown. There were the biggest differences among the drive configurations in this type of duty.

Fig. 26 will be described in the following text.

There are five sections in Figs. 26 and 27 (from the top to bottom): drive cycle, tractive effort with power on wheels, diesel engine power and speed, battery power and state of charge, power-bus related quantities (power distribution between diesel engine and battery).

If the required and available quantities visible in Figs. 26 and 27 overlap than no limitation in component occurs (component is able to deliver requested power).

Train is always moving in the following manner: acceleration to the calculated speed, coasting, braking to stop.

The achieved acceleration is higher compared to the conventional diesel-electric variant due to addition of batteries even after the diesel engine power was lowered from $970 \mathrm{~kW}$ to $403 \mathrm{~kW}$. Power on wheels is over $1000 \mathrm{~kW}$ for short periods. This slightly reduces time to finish drive cycle.

The battery is capable to supply the required power most of the time. The battery is recharging during decelerations and if the vehicle stops. There is a charging power limitation visible during the last two decelerations due to high weight of the train.

The battery is charged during decelerations and when the vehicle stops. The battery charging is stopped if the state of charge reaches $95 \%$. Simulation starts with the battery charged to $95 \%$. The state of charge is visible as "Battery SOC" in Fig. 27. 

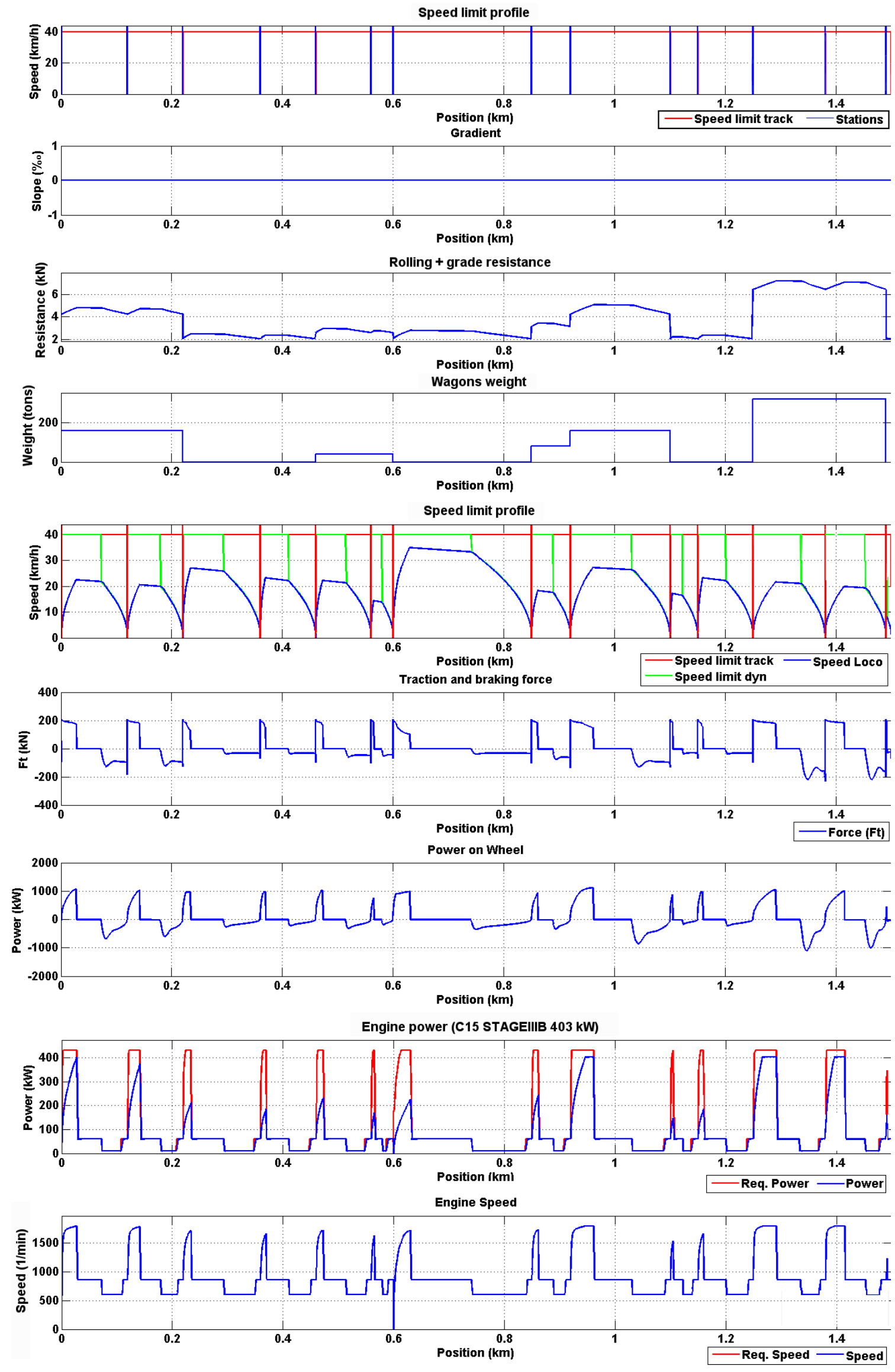

Fig. 26 Selected quantities in duty number 5 (sorting coaches on shunting yard). 

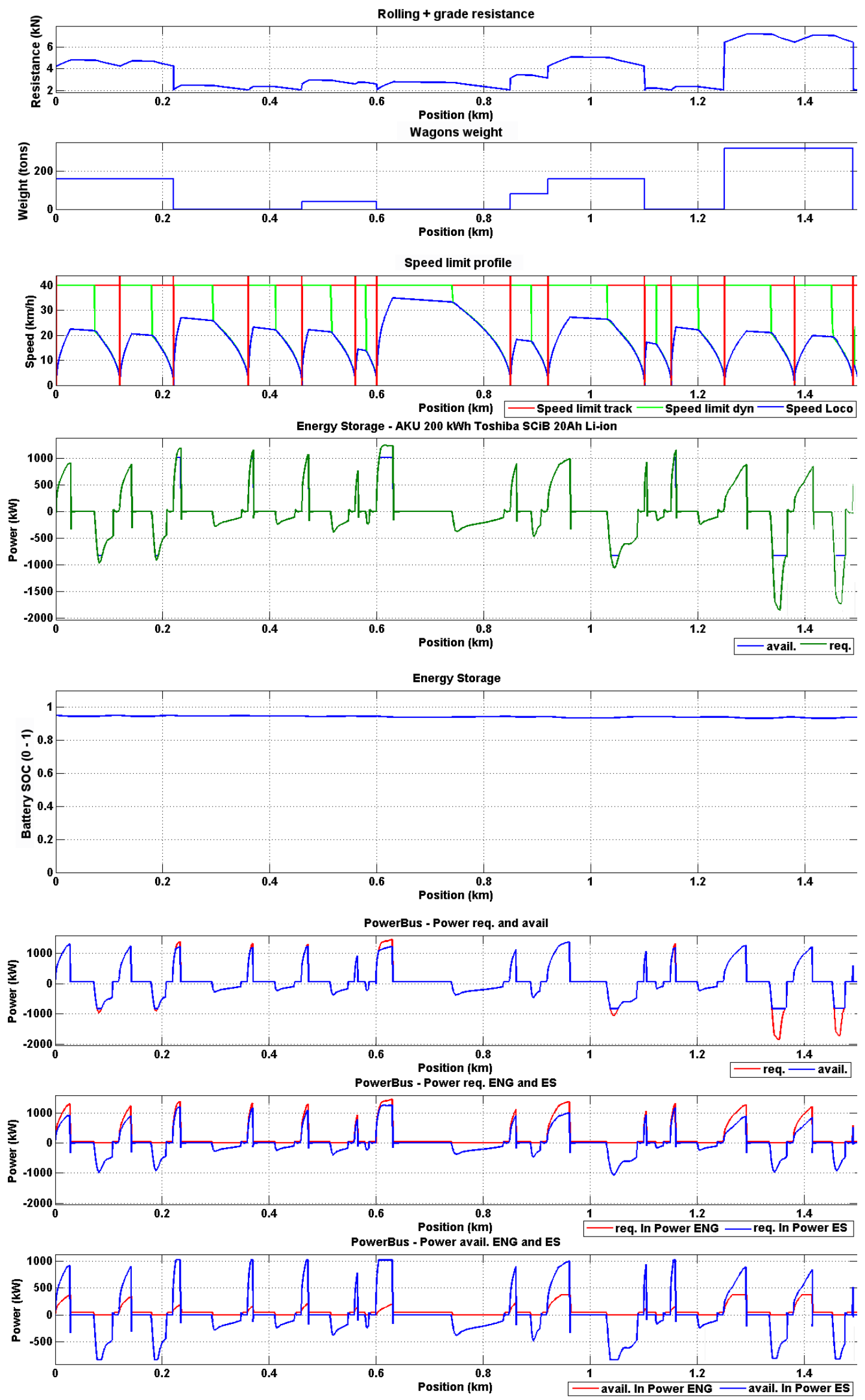

Fig. 27 Selected quantities in duty number 5 (sorting coaches on shunting yard) - continued. 
There is a difference between the required and available diesel engine power. The difference is caused by the amount of time needed to increase diesel engine speed in order the engine is able to deliver the requested power. During the acceleration phase of the engine the power to wheels is supplied by batteries. The maximum engine power is not reached because train weight is low. The batteries are able to supply enough power during vehicle accelerations.

Power distribution between the diesel engine (ENG) and batteries (ES) is visible in the bottom of Fig. 27. The required power in the DC-bus (PowerBus in Fig. 27) is the power demanded by the traction motors and auxiliary devices. The available power is the real power delivered from the DC-bus to the traction motors and auxiliary devices. The difference between the required and available power of the diesel engine (ENG in Fig. 27) is supplied by the batteries (ES in Fig. 27). The power supplied by the batteries is at least two times higher than the power supplied by the diesel engine (it depends on the actual situation of course). The battery capacity changes only a little from the initial value during the drive cycle because of low train weight and short distance. Energy recuperation occurs at every deceleration. The duty lasts 86.1 minutes, which is almost the same value as with the conventional diesel-electric variant (85.9 minutes).Fuel consumption of the diesel engine is shown in Fig. 28.

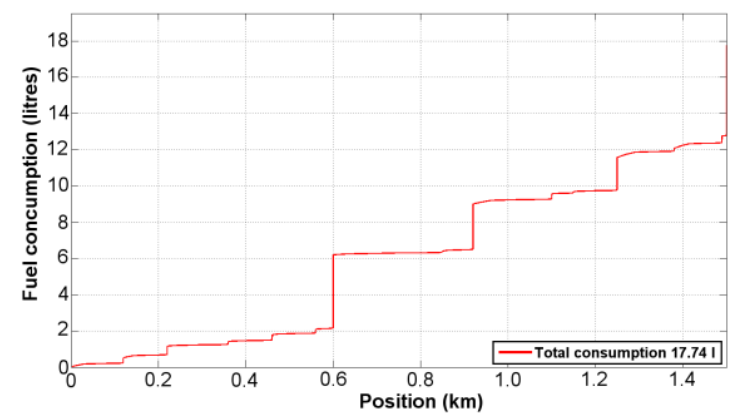

Fig. 28 Fuel consumption in the duty number 5.

The fuel consumption spike at the right end of Fig. 28 is caused by battery charging. The vehicle stops and charges batteries with full diesel engine power to the same level as at the beginning of the drive cycle $(95 \%$ of the total capacity). In this type of duty the fuel consumption of the hybrid vehicle is $31 \%$ lower compared to the conventional diesel variant.

\section{Simulation Results}

The proposed three variants of locomotive were tested on eight variants of duties. Total 24 simulations were done. The heaviest duties were duties number 1,2, 3 and 8 where the total train weight varies between 500 and 1900 tons.

The main observed quantity is the total fuel consumption during the simulation. Big differences in the fuel consumption among variants can be seen in Fig. 29. The biggest fuel consumption was achieved with the conventional diesel-electric propulsion. The fuel consumption was strongly reduced by hybrid propulsion.

The fuel consumption was reduced by approx. $27 \%$ (mean value) using the "Hybrid, diesel preferred" variant. The amount of fuel saving depends on the type of track, weight of wagons and power consumed by auxiliary devices. The energy recuperation helps considerably.

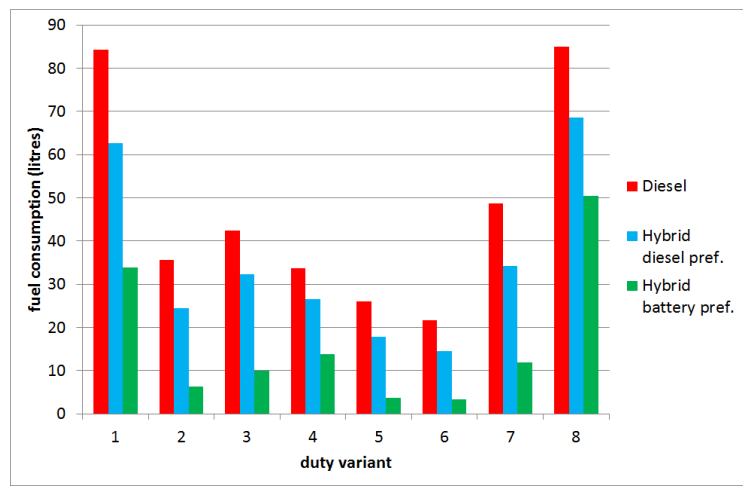

Fig. 29 Fuel consumption at the end of duty.

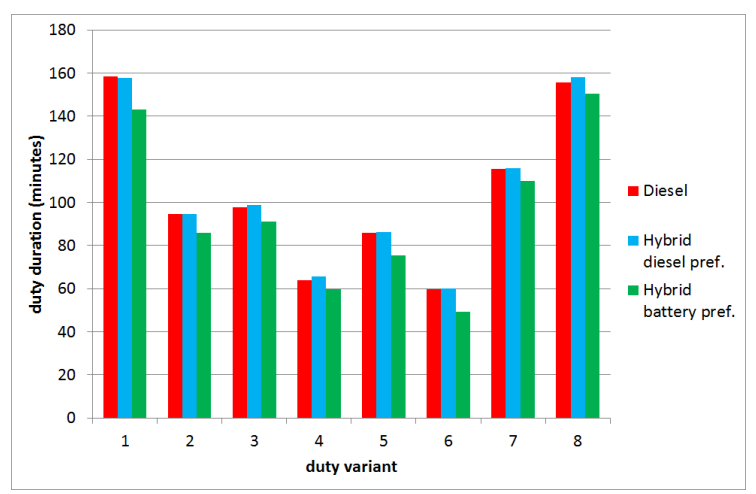

Fig. 30 Duty duration.

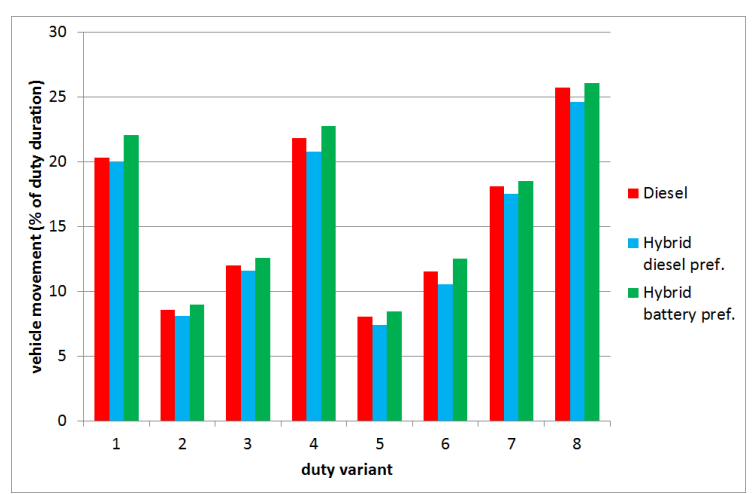

Fig. 31 Percentage time of the vehicle movement.

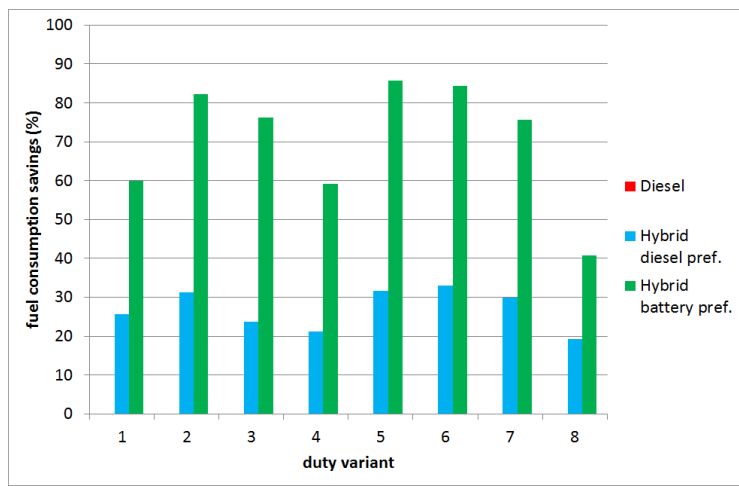

Fig. 32 Fuel consumption savings (compared to conventional Diesel). 
The last locomotive variant "Hybrid, battery preferred" has reduced the fuel consumption even more. Idling of the diesel engine was avoided at all. The diesel engine was switched off completely during shunting. The battery capacity was high enough to supply vehicle movement during the whole shunting duty.

The fuel consumption was reduced by approx. $70 \%$ (mean value) in comparison to the conventional dieselelectric variant. The biggest energy savings is in accelerations and in the parts of cycle where the vehicle is not moving. At the end of the driving cycle the diesel engine is started to charge the battery to $95 \%$ of the nominal capacity. The diesel engine charges battery with maximum power and runs at the optimal operating point with low specific fuel consumption. The duty duration was even a little bit shortened because the vehicle has higher dynamics then the conventional diesel-electric propulsion.

The locomotive is able to run all types of presented duties as fast as the conventional diesel-electric variant all the day without need for extra time for charging batteries.

\section{CONCLUSION}

The contribution of the series hybrid drive used in the shunting locomotive is strongly dependent on the type of duty. Duties used in the simulations were created so that they correspond to reality. The contribution of hybrid propulsion is high in duties containing long idling intervals. The fuel consumption can be reduced drastically in these cases. The fuel savings is achieved by following precautions: diesel engine spends less time in transients, less powerful engine is used, elimination of engine idling, lessen power to auxiliary devices in case the engine is stopped. If character of the duty is close to the line service rather than shunting (service on siding track for example), hybridization is less effective. The fuel consumption savings is not so high but still very good (tens of percent). In case of used control strategy used it is clear that the battery preferred operation is the best (the lowest fuel consumption is achieved). In this case the diesel engine runs only if the battery state of charge is low and charging occurs with high efficiency - the diesel engine operates at point with low specific fuel consumption, engine transients are eliminated. Charging from the diesel engine was the only variant used in simulations. If the batteries would be charged from the distribution grid at night, economic contribution would be even higher. The paper did not deal with economic aspects of hybridization.

\section{ACKNOWLEDGMENT}

The research was supported by the TACR grant "Competence Centre of Railway Vehicles" No. TE01020038.

\section{REFERENCES}

[1] NOVÁK, Jaroslav, Václav LENOCH, Ladislav MLYNAŘíK, Zdeněk MAŠEK a Ondřej SADÍLEK. Sériové hybridni pohony pro drážni vozidla. Zpráva č. KEEZ-T-12.05-15. Projekt č. 50680/56/TE520038. Pardubice, 2015.

[2] Simulační model sériového hybridního pohonu posunovací lokomotivy. In: LENOCH, Václav a Zdeněk MAŠEK. XXXIV. Celostátní konference o elektrických pohonech. Praha: Česká elektrotechnická společnost, 2015, s. 17. ISBN 978-80-02-02592-4.

[3] MAŠEK, Zdeněk a Václav LENOCH. Koncepce simulačního SW pro analýzu energetických toků trakčního pohonu hybridních kolejových vozidel. In: Elektrotechnická zařizeni v dopravě. Pardubice, 2015

[4] NOVÁK, Jaroslav a Ladislav MLYNǍ̌́IK. Vybrané problémy implementace simulačních modelů elektrických strojů v hnacích vozidlech. In: Elektrotechnická zařizeni v dopravě. Pardubice, 2015.

[5] NOVÁK, J., MLYNAŘíK, L. a LELEK, T.: Vybrané problémy implementace simulačních modelů elektrických strojů $\mathrm{v}$ hnacích vozidlech, Sborník z konference Elektrotechnická zařízení v dopravě 2015. Pardubice: Univerzita Pardubice, 2015. ISBN 97880-7395-878-7.

[6] PÁCHA, Matěj. Hybridní pohon kolejových vozidel. Žilina, 2010. Disertační práce. Žilinská univerzita v Žilině.

[7] GUZZELLA, Lino a Christopher ONDER. Introduction to Modeling and Control of Internal Combustion Engine Systems. Germany: Springer Verlag, 2004, 300 s. ISBN 978-3-540-22274-3. 